\title{
PREDATORY ABILITY OF Arthrobotrys musiformis AND Monacrosporium thaumasium ON Scutellonema bradys
}

\author{
Ana Cristina Fermino Soares ${ }^{1 *}$; Carla da Silva Sousa²; João Luiz Coimbra³; Gisele da Silva \\ Machado$^{1}$; Marlon da Silva Garrido²; Nailson dos Santos Almeida ${ }^{1}$ \\ ${ }^{1}$ UFBA - Escola de Agronomia - Depto. de Fitotecnia, 44380-000 - Cruz das Almas, BA - Brasil. \\ ${ }^{2}$ UFBA - Programa de Pós-Graduação em Ciências Agrárias. \\ ${ }^{3}$ UNEB/Campus IX - Depto.de Ciências Humanas, 47800-000 - Barreiras, BA - Brasil. \\ *Corresponding author <acsoares@ufba.br>
}

\begin{abstract}
Scutellonema bradys (Steiner \& LeHew) Andrassy is the most important yam nematode in the State of Bahia, Brazil, being responsible for the decay of yam tubers, known as dry rot disease. Nematodetrapping fungi are potential biocontrol agents against plant parasitic nematodes. The in vitro predatory ability of Arthrobotrys musiformis Drechsler and Monacrosporium thaumasium Drechsler on S. bradys was evaluated. The fungi were grown in PDA medium, than transferred to the center of Petri dishes with $2 \%$ agar plus water. After 14 days of the fungal cultures incubation, 150 nematodes were added to the dishes. For a period of 5 days, at 24-hour intervals, the number of captured nematodes was counted. Both fungi formed trapping structures of single ring and three-dimensional adhesive network types, 24 hours after the addition of the nematodes to the fungal cultures. The percentage of nematodes captured by each fungus increased linearly with time, reaching $94.6 \%$ and $97.3 \%$ of captured nematodes by $A$. musiformis and $M$. thaumasium, respectively, at the fifth day of evaluation. Both fungi presented good predatory ability upon $S$. bradys. This is the first report of nematophagous fungi capturing $S$. bradys. Further studies should evaluate the potential of these fungi as biocontrol agents of $S$. bradys in yam plantations. Key words: Dioscorea cayennensis Lam., nematophagous fungi, yam dry rot, biological control
\end{abstract}

\section{CAPACIDADE PREDATÓRIA DE Arthrobotrys musiformis E Monacrosporium thaumasium A Scutellonema bradys}

\begin{abstract}
RESUMO: Scutellonema bradys (Steiner \& LeHew) Andrassy é o nematóide mais importante da cultura do inhame (Dioscorea cayennensis Lam.) no Estado da Bahia, Brasil, responsável pela necrose superficial das túberas, conhecida como casca preta do inhame. Os fungos nematófagos são potenciais agentes de biocontrole contra nematóides fitoparasitos. A atividade predatória de Arthrobotrys musiformis Drechsler a S. bradys foi avaliada in vitro. Os fungos foram multiplicados em meio BDA durante 15 dias, transferidos para o centro de placas de Petri contendo 2\% de agar-água e após 14 dias de incubação, foram adicionados 150 nematóides. Durante cinco dias, em intervalos de 24 horas, foi quantificado o número de nematóides capturados pelos fungos. Ambos os fungos formaram estruturas de captura do tipo anéis simples e malha adesiva tri-dimensional, 24 horas após a infestação das placas com S. bradys. A percentagem de nematóides capturados por cada fungo aumentou linearmente com o tempo, atingindo 94,6\% e 97,3\% de captura por A. musiformis e M. thaumasium, respectivamente, no quinto dia de avaliação. Ambos os fungos apresentaram boa capacidade predatória sobre $S$. bradys. Esse é o primeiro relato de fungos nematófagos capturando $S$. bradys. Estudos futuros deverão avaliar o potencial destes agentes de biocontrole como alternativa para o controle de $S$. bradys em plantios de inhame.

Palavras-chave: Dioscorea cayennensis Lam., fungos nematófagos, casca preta do inhame, controle biológico
\end{abstract}

\section{INTRODUCTION}

Yam (Dioscorea cayennensis Lam.) is an important crop in the Northeastern region of Brazil, being sold at the internal and external market. The yam tubers are attacked by many plant parasitic nematodes, among which the yam nematode
Scutellonema bradys (Steiner \& LeHew) Andrassy is the most important one in the State of Bahia (Garrido et al., 2003). S. bradys is responsible for the decay of yam tubers, known as dry rot disease, which affects the productivity, quality and commercial value of the tubers (Moura, 2005; Kwoseh et al., 2002). 
The control of this plant parasitic nematode is difficult, since the utilization of fumigant and systemic nematicides have not been recommended for yam crop in Brazil due to problems with toxicity and their high cost (Moura, 2005). Therefore, it has become necessary to develop alternative control methods.

Biological control with natural enemies of nematodes, such as nematode-trapping fungi, can be a valuable alternative for the development of strategies to control $S$. bradys in yam plantations. Nematophagous fungi, from all major taxonomic groups of fungi, have been widely studied around the world in several crops for the control of plant parasitic nematodes (Araújo, 1998; Ribeiro et al., 1999; Maia et al., 2001; Bordallo et al., 2002; Nordbring-Hertz et al., 2002). These fungi form sophisticated hyphal structures, such as three-dimensional adhesive nets, knobs, branches or rings, in which the nematodes are captured by adhesion or mechanically, and are used by the fungi as a nutrient source (Nordbring-Hertz et al., 2002).

However, studies with $S$. bradys and nematophagous fungi have not been reported in the literature. The objective of this work was to verify the in vitro predacious ability of the nematophagous fungi Arthrobotrys musiformis Drechsler, and Monacrosporium thaumasium Drechsler on S. bradys.

\section{MATERIAL AND METHODS}

A. musiformis and $M$. thaumasium were isolated from rhizosphere soil of pigeon pea (Cajanus cajan L.), in Cruz das Almas, State of Bahia, Brazil. The method of soil spreading on plate (Barron, 1977), modified by Santos (1991), was used to isolate the fungi. The taxonomic identification of the fungi was done by Dr. Arlete S. Maia (Universidade Estadual de Santa Cruz) through the morphometric characteristics of the fungus isolates.

For evaluation of the predatory activity of $A$. musiformis and $M$. thaumasium on S. bradys, one disc of $0.5 \mathrm{~cm}$ diameter, from a pure culture of each fungus, grown in potato dextrose agar medium for 15 days, at $25^{\circ} \mathrm{C}$, was transferred to the center of a Petri dish with water-agar medium (2\% agar) and the cultures (10 Petri dishes for each fungus) were incubated at a temperature of $25^{\circ} \mathrm{C}$, for 14 days. After this incubation period, a suspension of 150 nematodes ( $S$. bradys) was added to each full-grown Petri dish culture of the fungus. The nematodes were obtained from infested yam tubers with symptoms of dry rot, by the method of blending in a household blender, at medium speed, followed by centrifugation in sucrose solution and caolim, as described by Coolen \& D'Herde (1972). For a period of five days, at 24-hour time intervals, the nematodes captured by each fungus were counted, un- der a stereoscopic microscope. The experimental design was entirely randomized with ten replicates for each fungus. The data of percentage of captured nematodes was transformed in arc sen $\sqrt{x / 100}$ (Banzatto \& Kronka, 1992). The analysis of variance (ANOVA), Ttest, and regression analysis were performed with the statistical SISVAR (Ferreira, 2000).

\section{RESULTS AND DISCUSSION}

Both A. musiformis and M. thaumasium formed trapping structures twenty-four hours after the addition of $S$. bradys to full-grown cultures of each fungus. The trapping structures consisted of single rings and fully developed three-dimensional adhesive networks, which were formed only in the presence of the nematodes, indicating that these fungi are dependent on the external stimuli provided by the nematodes for induction of trap formation. Saprophytic nematophagous fungi such as Arthrobotrys spp., have a unique ability to change their morphology, with the development of an adhesive network trap (single rings or tree-dimensional networks), to increase their parasitic ability (Nordbring-Hertz et al., 2002). $M$. thaumasium also develops three-dimensional network traps (Kano et al., 2004).

The percentage of captured nematodes by $A$. musiformis (Figure 1) and M. thaumasium (Figure 2) did not differ $(P \leq 0.05)$ for the evaluation periods of one, four and five days after addition of the nematodes. However, at the second and third day of evaluation $M$. thaumasium, captured higher proportion of nematodes (29.2\% and $41.9 \%$, respectively) than A. musiformis (19.3\% and 27.1\%, respectively). Five days after the first observation of trapping structures, $94.6 \%$ and $97.3 \%$ of the nematodes were trapped by A. musiformis (Figure 1) and M. thaumasium (Figure 2), respectively. Therefore, M. thaumasium was more effective in capturing $S$. bradys at two and three days after contact with this nematode, but both fungi became equally effective after this period.

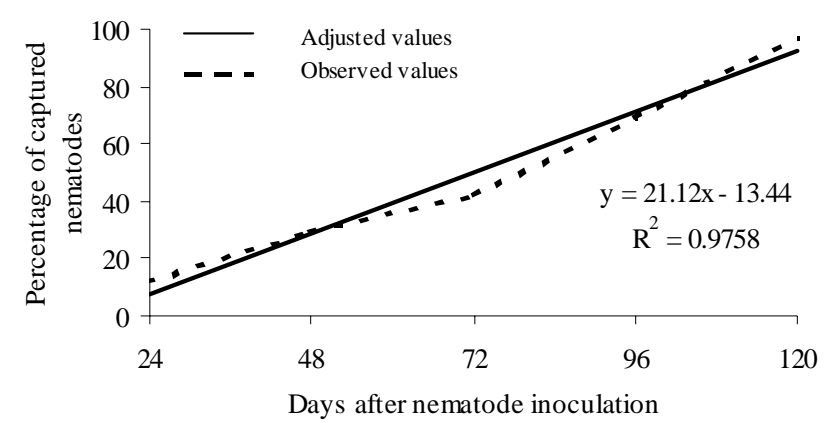

Figure 1 - Percentage of nematodes (Scutellonema bradys) captured by the nematophagous fungus Arthrobotrys musiformis. 


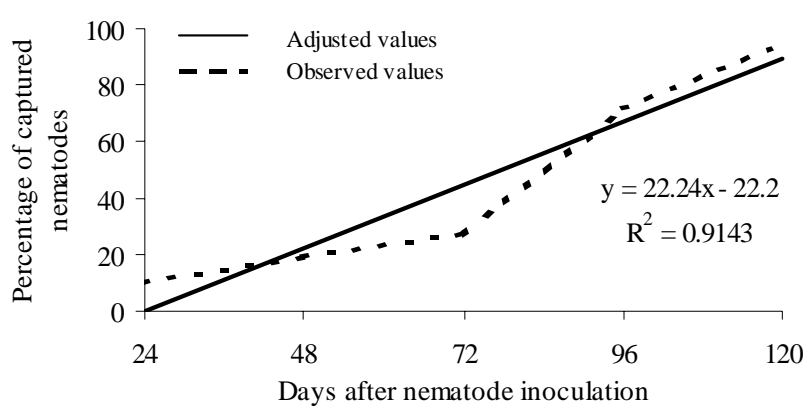

Figure 2 - Percentage of nematodes (Scutellonema bradys) captured by the nematophagous fungus Monacrosporium thaumasium.

The percentage of nematodes captured by each fungus increased linearly with time, demonstrating good trapping ability of both fungi on S. bradys. The capacity of these nematophagous fungi to capture nematodes is well known (Araújo, 1998; Gomes et al., 2001; Bordallo et al., 2002; Nordbring-Hertz et al., 2002; Kano et al., 2004). However, the type of nematode-trapping structures formed depends on the species or even the strains of species, and on both biotic and abiotic environmental conditions. The nematode is the most important biotic factor which induces the formation of trapping structures (Nordbring-Hertz et al., 2002).

This is the first report of the ability of $A$. musiformis and $M$. thaumasium to develop trapping structures and capture the yam tuber dry rot nematode $S$. bradys. In the present work, it was demonstrated that A. musiformis and M. thaumasium can be considered as potential biocontrol agents for the development of strategies to control S. bradys. A. musiformis is found most frequently in tropical areas, with an abundant and ubiquitous occurrence (Nordbring-Hertz et al., 2002). Further research is necessary to study the capacity of $A$. musiformis and $M$. thaumasium for yam rhizosphere colonization, which is an important characteristic of biological control agents for soilborne diseases, and also the ability of these fungi, and other nematophagous fungi to capture and control S. bradys in the soil environment. Nematophagous fungi from yam rhizosphere soil should also be isolated and studied. The development of strategies for increasing the population and activity of these fungi in yam production areas may also be an alternative to control $S$. bradys.

\section{ACKNOWLEDGEMENTS}

The authors thank: Fundação de Amparo à Pesquisa do Estado da Bahia (FAPESB) for the research financial support and undergraduate scientific initiation scholarship, Conselho Nacional de Desenvolvimento Científico e Tecnológico (CNPq) for the post-doctor and undergraduate scientific initiation scholarships, Coordenação de Aperfeiçoamento de Pessoal de Nível Superior (CAPES) for M.Sc. scholarships, and Dr. Arlete S. Maia form the Universidade Estadual de Santa Cruz (UESC), in the city of Ilhéus, Bahia State, Brazil, for the taxonomic identification of the nematophagous fungi.

\section{REFERENCES}

ARAÚJO, J.V. de. Predacious activity of Arthrobotrys spp. isolates on infective Cooperia punctata larvae. Brazilian Journal of Veterinary Research and Animal Science, v.35, p.9-11, 1998.

BANZATTO, D.V; KRONKA, S. do N. Experimentação agrícola. Jaboticabal: FCAV/UNESP, 1992. 247p.

BARRON, G.L. The nematode-destroying fungi. Guelph: Canadian Biological Publications, 1977.

BORDALLO, J.J.; LOPEZ-LLORCA, L.V.; JANSSON, H.B.; SALINAS, J.; PERSMARK, L.; ASENSIO, L. Colonization of plant roots by egg-parasitic and nematode-trapping fungi. New Phytologist, v.154, p.491-499, 2002.

COOLEN, W.A.; D’HERDE, C.J. A method for the quantitative extraction of nematodes from plant tissue. Ghent: State Agricultural Research Centre, 1972. 77p.

FERREIRA, D.F. Análises estatísticas por meio do Sisvar para Windows versão 4.0. In: REUNIÃO ANUAL DA REGIÃO BRASILEIRA DA SOCIEDADE INTERNACIONAL DE BIOMETRIA, 45., São Carlos, 2000. Programas e resumos... São Carlos: UFSCar, 2000. p. 255-258.

GARRIDO, M. da S; SOARES, A.C.F; MENDES, L. do N.; PEREZ, J.O. Novas tecnologias para a produção do inhame (Dioscorea cayennensis Lam.) no Estado da Bahia. Revista Bahia Agrícola, v.6, p.19-22, 2003.

GOMES, A.P.S.; VASCONCELOS, R.S.; RAMOS, M.L.; GUIMARÃES, M.P.; YATSUDA, A.P.; BRESSAN-VIEIRA, M.C.R. In vitro interaction of Brazilian strains of the nematode-trapping fungi Arthrobotrys spp. on Panagrellus sp. and Cooperia punctata. Memórias do Instituto Oswaldo Cruz, v.96, p.861-864, 2001.

KANO, S.; AIMI, T.; MASUMOTO, S.; KITAMOTO, Y.; MORINAGA, T. Physiology and molecular characteristics of a pine wilt nematodetrapping fungus, Monacrosporium megalosporium. Current Microbiology, v.49, p.158-164, 2004.

KWOSEH, C.; PLOWRIGHT, R.A.; BRIDGE, J. The yam nematode: Scutellonema bradys. In: STARR, J.L.; COOK, R.; BRIDGE, J. (Ed.) Plant resistance to parasitic nematodes. Wallingford: CABI Publishing, 2002. p.221-228.

MAIA, A.S.; SANTOS, J.M.; DI MAURO, A.O. Estudo in vitro da habilidade predatória de Monacrosporium robustum sobre Heterodera glycines. Fitopatologia Brasileira, v.26, p.732-736, 2001.

MOURA, R.M. de. Doenças do Inhame-da-costa (Dioscorea cayennensis). In: H. KIMATI, H.; AMORIM, L.; RESENDE, J.A.M.; BERGAMIM FILHO, A.; CAMARGO, L.F.A. (Ed.). Manual de fitopatologia: Doenças das plantas cultivadas. São Paulo: Ceres, 2005. p.415-419.

NORDBRING-HERTZ, B.; JANSSON, H.-B.; TUNLID, A. Nematophagous fungi. In: ENCYCLOPEDIA OF LIFE SCIENCES. Basingstoke: Macmillan Publishers, 2002. v.12, p.681-690.

RIBEIRO, R.C.F.; FERRAZ, S.; MIZOBUTSI, E.H.; MENEZES, M. Levantamento de espécies de Monacrosporium predadoras de nematóides de diversas regiões brasileiras. Nematologia Brasileira, v.23, p.41-47, 1999.

SANTOS, M.A. Detecção, identificação e avaliação do potencial antagonista de fungos nematófagos em solos do Brasil. Viçosa: UFV, 1991. (Dissertação - M.S.).

Received August 16, 2005

Accepted June 06, 2006 